\title{
Assessment of Relative Efficiency of Countries in Attaining Human Development Sub indexes
}

\author{
Mohsen Mehrara ${ }^{1, *}$, Majid Vaziri Duzin ${ }^{2}$, Abolfazl Abbasi ${ }^{1}$ \\ ${ }^{1}$ Faculty of Economics, University of Tehran, Tehran, Iran \\ 2Department of Economics, Faculty of Management and Economics, \\ Shahid Bahonar University of Kerman, Iran \\ *E-mail address: mmehrara@ut.ac.ir
}

\begin{abstract}
Competitiveness and human development are two major aspects of nations' performance. However, the main objective of competitiveness should be to improve human development. In the current study, we aimed to examine the relative efficiency of countries in achieving the aforementioned target. In other words, the question is whether competitiveness has led to human development. To this end, we selected 31 countries with the same category in human development (high human development) and also with available data on competitiveness and its components. Due to the nature of the study, we used Data Envelopment Analysis (DEA) method. The model used in this study employed three subindexes of global competitiveness including basic requirements, efficiency enhancers, and innovation and sophistication factors as input variables and three subindexes of human development including life expectancy at birth, mean years of schooling, and per capita national income as output variables. Since, as noted, the goal of countries (DMUs) is to improve human development; this study employed an output-oriented DEA model. Though, a DEA model with either constant or variable return to scale could be used, this paper employs DEA with constant return to scale because variable case has extended to accommodate scale effects while in our case (where countries in the role of units under assessment are large enough) intrinsic scale effects do not exist and also CRS models have higher separable power for differentiating efficient and inefficient units. And finally after running the model we found that 9 out of 31 assessed countries are technically efficient which implies that these 9 countries have used competitiveness subindexes to attain expected values of human development sub-indexes. In 2012 Iran is an inefficient unit, having a technical efficiency rank of 19th among the assessed countries. As in this paper there are two kinds of variables, i.e. input and output variables, the most effective subindex which have lowered Iran's rank are life expectancy at birth for input variables and efficiency enhancers for output variables. Moreover, Albania and Venezuela have been introduced as reference set for Iran in this year.
\end{abstract}

Keywords: Competitiveness; Human Development; DEA; Relative Efficiency

\section{INTRODUCTION}

Competitiveness is one of the topics addressed intensively by several researchers and analysts in recent decades. In seeking to explain patterns of international competition, several researchers have emphasized the importance of characteristics of the home country in 
determining the competitive position of its firms in international markets (Ülengin et al. 2011). On the other hand, concept of development has changed over last decades. Until 1970s, economic development was measured in term of per capita income, assuming that increased per capita income improves all aspects of people's life. Thus, by this point of view, economic growth was considered as the principal axis of the development. The main problem with this view is neglecting justice in having personal opportunities in order to achieve success. Considering defects of per-capita-income approach, "development" researchers tried to introduce a socioeconomic index and the Human Development Index therefore was introduced (Sadeghi et al, 2007). According to the importance of the both explained fields, present study has set to rank the countries in term of utilization of their competitiveness in order to improve their human development. The second section of the paper expresses the competitiveness and the human development index as the two important aspects of performance of nations as well as relationship between them. The third section describes the proposed methodology, data envelopment analysis. In the fourth section, the model has been ran and sensitivity analysis has been reported. Finally, conclusions are given.

\section{COMPETETIVENESS AND HUMAN DEVELOPMENT: TWO ASPECTS OF PERFORMANCE OF COUNTRIES}

\subsection{Competitiveness}

Each year, selected organizations, such as the World Economic Forum (WEF) and the Institute for Management Development (IMD), apply several hundred objective and subjective indicators to assess the wealth created by the world's nations, and subsequently publish rankings of national competitiveness (Ülengin et al. 2011). These rankings can be used for policy making or other purposes. The competitiveness can be assessed either in the view of macro or micro contexts. This study uses macro view announced by WEF and OECD. WEF defines competitiveness as below:

"We define competitiveness as the set of institutions, policies, and factors that determine the level of productivity of a country. The level of productivity, in turn, sets the level of prosperity that can be reached by an economy. The productivity level also determines the rate of return obtained by investments in an economy, which in turn are the fundamental drivers of its growth rates. In other words, a more competitive economy is one that is likely to grow faster over time (WEF, Global Competitiveness Report, 2013).

According to WEF records, global competitiveness index is combined of following subindexes and their components is presented: 


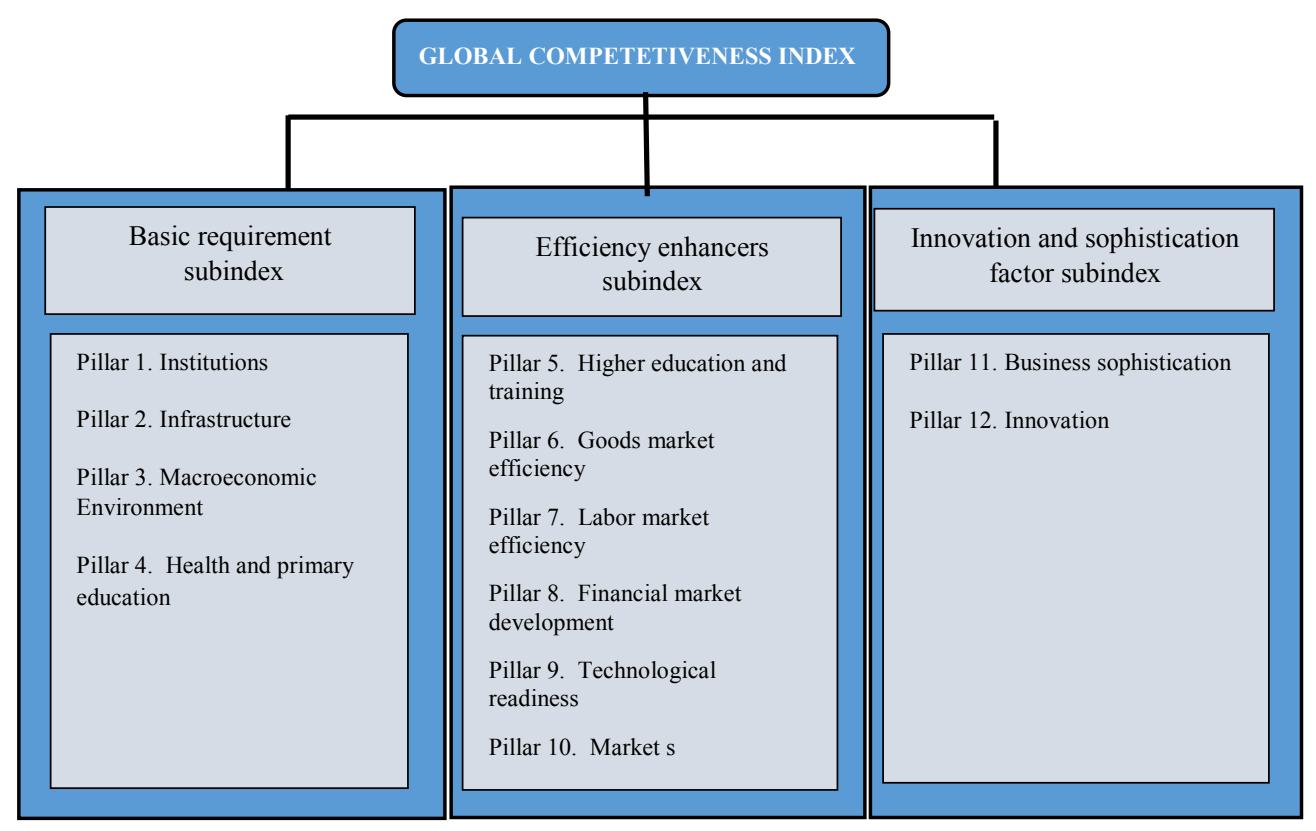

\subsection{Evaluation of Human Development}

The concept of human development is based on the fact that improvement of nations cannot be measured simply by means of per capita income, but in order to have better life it is essential to have opportunities to grow individual (and social-level) capabilities and capacities. Therefore, according to United Nations Development Programme, human development is the process of expansion of the choices and capabilities for everyone, wherever they live (UNDP, 2013). Human Development Index was introduced in 1990 as a new index of development. This index measures three basic dimensions: healthy longevity, measured by life expectancy at birth, education measured by mean years of schooling and expected years of schooling, and acceptable living standards measured by per capita income.

Every subindex is a value between zero and one. Life expectancy and two indices of education are calculated by the following formula:

$$
X_{i}=\frac{x_{i}-\min _{i}}{\operatorname{maxx}_{i}-\min x_{i}}
$$

But for per capita income, natural logarithm form is used.

\subsection{Relation Between Competitiveness and Human Development: A Brief Review of the Literature}

Ranis et. al., (2000) in their study survey the relationship between economic growth and human development for 1960-92. Their sample consists of 35 to 76 developing countries, according to the availability of data for particular variables. The results show a significant relationship in both directions. Economic growth provides essential resources required for sustainable improvement in human development and, in the other hand, improvement in 
quality of labor force is considered as an important component of economic growth. Thus, there is a two-way direction between economic growth and human development.

Ulengin and Onsel (2002) employ a stronger and more powerful method to assess competitiveness power of nations. Their method confirms significantly results of world competitiveness reported by world economic forum.

Wang et al. (2007) stress the role of technology development in national competitiveness. In their study, Southeast Asian countries are divided into three patterns by means of a cluster framework: countries with same rank on technology development and national competitiveness, countries with same rank on technology and economic performance, and finally, those with same rank on technology development and management capability. The results show that Singapore, Malaysia, Thailand, and Laos follow the first pattern, Singapore, Thailand, the Philippines and Laos have the same rank on the second pattern, and Malaysia and Thailand follow the third pattern.

Önsel et al. (2008) are searching a way to evaluate, and thus, rank competitiveness of nations. This methodology contains three steps: in the first step they rank countries using cluster analysis and 178 indices. Then in the second step, they use neural networks method to weight each of the indices for every country. And in the final step, they rank countries based on the weights resulted from second step.

Davies (2009) studies the impact of government expenditures on the social welfare measured by human development index using dynamic panel data. He results an optimum size for government size subject to a given level of social welfare.

Reiter and Steensma (2010) assess the effect of foreign direct investment (FDI) policy and corruption on human development. Their results show that when FDI policy restricts inflow foreign investors from entering some economic sectors, the effect of FDI on improvement in human development will be more strongly positive.

Ülengin, Kabak, Önsel, et al. (2011) assess the impact of competitiveness of nations on human development. They firstly evaluate 45 countries based on data envelopment analysis. Then, they use international competitiveness sub-indices as input variables and human development sub-indices as output variables. Finally, neural networks analysis is used to identify the factors with the most effect on efficiency score of countries.

\section{FRAMEWORK OF THE PROPOSED METHODOLOGY}

Data Envelopment Analysis is based on several optimizations using linear programming known as nonparametric technique. In the foregoing technique, efficiency frontier is constructed by a set of points resulted from linear programming. In order to determine the points, one can assume either constant returns to scale or variable returns to scale. This technique, after a set of optimizations, illuminates whether decision-making unit (DMU) is within the efficiency frontier. And hereby, efficient and inefficient units are separated. In the DEA method, one can either maximize the output subject to a specific input (input-oriented), or minimize the input subject to a specific output (output-oriented). DEA method envelopes all the available data. This technique makes it possible to measure efficiency of DMUs with several outputs. Also, in the DEA method one can measure efficiency of DMUs without specifying kind of production function. 


\subsection{DEA Model with Constant Return to Scale (CSR)}

Charnes, Cooper and Rhodes, in 1987, presented their linear programming model assuming constant return to scale and input-oriented approach (Charnes, Cooper, and Rhodes 1978) which is known as CCR model. The model assumes that there exist $K$ inputs and $M$ outputs for each of the $N$ firms or DMUs. The amounts of input and output have been described respectively by $x_{i}$ and $y_{i}$ for $i$ th DMU, and $X$ is a $K \times N$ matrix of inputs and $Y$ is a $M \times N$ matrix of outputs. Furthermore, $u$ is a $M \times 1$ vector of weights of outputs and $v$ is a $K \times 1$ vector of weights of inputs where $u^{\prime}$ and $v^{\prime}$ are transpose of $u$ and $v$ respectively.

$$
\begin{gathered}
\max _{\mu, v}\left(\mu^{\prime} y_{i}\right), \\
\text { st } \quad v^{\prime} x_{i}=1 \\
\mu^{\prime} y_{i}-v^{\prime} x_{i} \leq 0, j=1,2, \ldots, N, \\
\mu, v \geq 0
\end{gathered}
$$

One can use (3-2) instead of (3-1) since the former has fewer restrictions

$$
\begin{gathered}
(K+M<N+1) . \\
\min _{\theta, \lambda} \theta, \\
s t-y_{i}+Y \lambda \geq 0, \\
\theta x_{i}-X \lambda \geq 0, \\
\lambda \geq 0,
\end{gathered}
$$

Where $\theta$ is a number and $\lambda$ is a $1 \times N$ vector of constants. $\theta$ represents $i$ th DMU's efficiency score, where $\theta \geq 1$ and if a firm stands on the efficiency frontier, we have $\theta=1$. (3-2) should be ran $N$ times to yield $\theta$ for each of the firms. The input-oriented model presented in (3-2) has constant return to scale which is known as CCR model and is the first data-envelopment-analysis model. It should be noted that in constant-returns-to-scale case, input and output-oriented approaches result in identical findings.

\subsection{DEA Model with Variable Return to Scale (VSR)}

Constant-return-to-scale assumption is instrumental if the DMUs operate in the efficient scale. Imperfect competition and financial restrictions are among the factors that make it inaccessible for DMUs to operate in efficient scale. Banker, Charnes and Cooper (1984) extended CCR model to include variable constant to scale (Banker, Charnes, and Cooper 1984). Their extended model is known as BCC model.

By augmenting the convexity restriction, $N_{1}^{\prime} \lambda=1$, to (3-2) one can result (3-3) which is called input-oriented DEA model with variable return to scale:

$$
\begin{gathered}
\min _{\theta, \lambda} \theta, \\
-y i+Y \lambda \geq 0 \\
\theta x i-X \lambda \geq 0 \\
N_{1}^{\prime} \lambda=1 \\
\lambda \geq 0
\end{gathered}
$$


where $N_{1}$ is a $N \times 1$ vector. Likewise, an output-oriented model with variable return to scale can be presented as below:

$$
\begin{gathered}
\max _{\phi, \lambda} \phi, \\
\text { st } \quad-\phi y i+Y \lambda \geq 0 \\
x i-X \lambda \geq 0 \\
N_{1}^{\prime} \lambda=1 \\
\lambda \geq 0
\end{gathered}
$$

where $1 \leq \phi \leq \infty$. In this model, $\frac{1}{\phi}$ represents technical efficiency score ranged between zero and one. Since technical efficiency in variable case differs between input and output-oriented approaches, (3-3) and (3-4) result in different technical efficiency scores.

\subsection{Reference Set and Input and Output Target}

In an industry if some producers are able to produce a given amount of outputs by use of minimum amount of inputs or, equivalently, to produce maximum amount of outputs using a given amount of inputs, then other producers operating in the industry are efficient when they act as same as the mentioned producer. In DEA method, an efficient firm or a combination of them is introduced as reference or pattern for the inefficient firm. Since the combined firm there not necessarily exists in the industry, it's known as a virtual efficient firm. In other words, reference firm for an inefficient firm can be an actual firm or, in general, a virtual firm. One of the advantages of DEA technique is finding the best virtual efficient firm for every actual firm (whether efficient or inefficient). Thus, reference set of an efficient firm will be itself.

Inefficient firms, in order to be efficient, have to have input and output amounts equal to the value of points depicted on efficiency frontier, which are named as "input target and output target for inefficient firms".

\subsection{Ranking of Efficient Units Using Andersen-Petersen (AP) Model}

Fundamental models of DEA technique (CCR and BCC models) result in efficiency scores to be ranged between zero and one. Thereupon, it's impossible to compare and rank completely efficient DMUs i.e. units which have equal efficiency score of one. Super-efficiency models were introduced to resolve this problem. First super-efficiency model is one introduced by Andersen and Petersen. In their model, the DMU under evaluation is excluded from the examination. Since efficient units don't form efficiency frontier, exclusion of them doesn't affect the frontier, and therefore, their efficiency score doesn't change in Andersen-Petersen model. But exclusion efficient units changes the frontier because they form the efficiency frontier. The extent of change in efficiency frontier caused by exclusion the efficient unit is a measure to rank efficient units. In other words, in AP model, efficiency score of DMUs with smaller-than-one efficiency score doesn't change but efficiency score of completely efficient units changes to one or greater than one. Thus, DMU with the best performance is one that has the greatest efficiency score (Andersen and Petersen 1993). 
AP model for the variable-return-to-scale case (BCC) is impractical and unresolvable. Hence, this study uses output-oriented AP model with constant return to scale (CCR). Thus the model takes the following form:

$$
\begin{array}{llr}
\text { st } \quad x_{i 0}-\sum_{\substack{j=1 \\
j \neq 0}}^{n} \mu_{j} x_{i j} \geq 0 & i=1, \ldots, m \\
& \eta_{0}-y_{r 0}-\sum_{\substack{j=1 \\
j \neq 0}}^{n} \mu_{j} y_{r j} & \\
\mu_{i} \geq 0 & j=1, \ldots, s
\end{array}
$$

\section{EVALUATION OF THE SELECTED COUNTRIES BASED ON DEA}

The present study uses data envelopment analysis. Regarding importance of human development as the ultimate aim of human activities as well as Boltho's emphasis on increasing national welfare as the goal of competitiveness (Boltho 1996), the model used in this study utilizes three subindexes of global competitiveness including basic requirements, efficiency enhancers, and innovation and sophistication factors (Report, Schwab, and Forum 2013) as input variables and three subindexes of human development including life expectancy at birth, mean years of schooling, and per capita national income (UNDP, 2013) as output variables. Since, as said, the goal of countries (DMUs) is to improve human development, this study applies an output-oriented DEA model. Moreover, a DEA model can be used with either constant or variable return to scale. This paper employs DEA with constant return to scale because variable case has extended to accommodate scale effects while in our case (where countries in the role of units under assessment are large enough) inherent scale effects don't exist and also CRS models have higher separability power for efficient and inefficient units (Dyson et al. 2001).

\subsection{Ranking of the Selected Countries}

We have following input and output variables in our DEA model:

Table 1. Input and output variables in DEA model in 2012.

\begin{tabular}{|c|c|c|c|c|c|c|}
\hline \multirow{2}{*}{ Country/Economy } & \multicolumn{3}{|c|}{ Input Variables } & \multicolumn{3}{c|}{ Output Variables } \\
\cline { 2 - 7 } & $\begin{array}{c}\text { basic } \\
\text { requirements }\end{array}$ & $\begin{array}{c}\text { efficiency } \\
\text { enhancers }\end{array}$ & $\begin{array}{c}\text { innovation } \\
\text { and } \\
\text { sophistication } \\
\text { factors }\end{array}$ & $\begin{array}{c}\text { life } \\
\text { expectancy } \\
\text { at birth } \\
\text { (year) }\end{array}$ & $\begin{array}{c}\text { mean years } \\
\text { of } \\
\text { schooling } \\
\text { (year) }\end{array}$ & $\begin{array}{c}\text { per capita } \\
\text { national } \\
\text { income } \\
\text { (dollar) }\end{array}$ \\
\hline Uruguay & 4.91 & 4 & 3.46 & 77.2 & 8.5 & 13333 \\
\hline Romania & 4.22 & 4.12 & 3.2 & 74.2 & 10.4 & 11011 \\
\hline Montenegro & 4.49 & 3.99 & 3.57 & 74.8 & 10.5 & 10471 \\
\hline Bulgaria & 4.63 & 4.18 & 3.3 & 73.6 & 10.6 & 11474 \\
\hline Saudi Arabia & 5.74 & 4.84 & 4.47 & 74.1 & 7.8 & 22616 \\
\hline
\end{tabular}




\begin{tabular}{|c|c|c|c|c|c|c|}
\hline Mexico & 4.64 & 4.31 & 3.79 & 77.1 & 8.5 & 12947 \\
\hline Panama & 4.83 & 4.36 & 3.83 & 76.3 & 9.4 & 13519 \\
\hline Poland & 4.15 & 3.83 & 2.96 & 74.7 & 10.2 & 9533 \\
\hline Malaysia & 5.38 & 4.89 & 4.7 & 74.5 & 9.5 & 13676 \\
\hline Trinidad & 4.95 & 3.85 & 3.33 & 70.3 & 9.2 & 21941 \\
\hline Kuwait & 5.21 & 3.98 & 3.36 & 74.7 & 6.1 & 52793 \\
\hline Russia & 4.79 & 4.26 & 3.16 & 69.1 & 11.7 & 14461 \\
\hline Kazakhstan & 4.86 & 4.24 & 3.25 & 67.4 & 10.4 & 10451 \\
\hline Albania & 4.24 & 3.8 & 3.11 & 77.1 & 10.4 & 7822 \\
\hline Cota Rica & 4.61 & 4.18 & 4.04 & 79.4 & 8.4 & 10863 \\
\hline Lebanon & 3.79 & 4.06 & 3.41 & 72.8 & 7.9 & 12364 \\
\hline Venezuela & 3.54 & 3.46 & 2.78 & 74.6 & 7.6 & 11475 \\
\hline $\begin{array}{l}\text { Bosnia and } \\
\text { Herzegovina }\end{array}$ & 4.33 & 3.75 & 3.28 & 75.8 & 8.3 & 7713 \\
\hline Georgia & 4.63 & 3.84 & 3 & 73.9 & 12.1 & 5005 \\
\hline Ukraine & 4.35 & 4.11 & 3.43 & 68.8 & 11.3 & 6428 \\
\hline Jamaica & 3.82 & 3.93 & 3.41 & 73.3 & 9.6 & 6701 \\
\hline Peru & 4.57 & 4.23 & 3.31 & 74.2 & 8.7 & 9306 \\
\hline Brazil & 4.49 & 4.52 & 3.97 & 73.8 & 7.2 & 10152 \\
\hline Ecuador & 4.42 & 3.68 & 3.32 & 75.8 & 7.6 & 7471 \\
\hline Armenia & 4.41 & 3.86 & 3.29 & 74.4 & 10.8 & 5540 \\
\hline Colombia & 4.4 & 4.13 & 3.58 & 73.9 & 7.3 & 8711 \\
\hline Iran & 4.69 & 3.81 & 3.46 & 73.2 & 7.8 & 10695 \\
\hline Oman & 5.69 & 4.4 & 3.91 & 73.2 & 5.5 & 24092 \\
\hline Azerbaijan & 4.76 & 4.05 & 3.68 & 70.9 & 11.2 & 8153 \\
\hline Turkey & 4.75 & 4.42 & 3.79 & 74.2 & 6.5 & 13710 \\
\hline Tunisia & 4.91 & 3.94 & 3.65 & 74.7 & 6.5 & 8103 \\
\hline
\end{tabular}

Source: competitiveness and human development reports

Table 1 shows the input and output variables of DEA model in 2012. First column in the table specifies 31 investigated countries which have similar human development index (high human development) as well as available data on competitiveness. Next three columns show input variables including three subindexes of competitiveness. Each of these unit-free subindexes can vary between 1 and 7. Finally, last three columns of the table 1 show the output variables being subindexes of human development.

We first calculate technical efficiency score of each country (DMU) by using model (32) and then in order to complete ranking, we run model (5-3) for countries for which efficiency score equaled by one to obtain score of these countries and rank all the countries. By doing the described procedure we have the following ranking: 
Table 2. Efficiency scores for countries as well as reference set for inefficient units in 2012.

\begin{tabular}{|c|c|c|c|c|c|}
\hline Country & $\begin{array}{l}\text { GCI } \\
\text { Rank }\end{array}$ & $\begin{array}{l}\text { HDI } \\
\text { Rank }\end{array}$ & $\begin{array}{c}\text { Technical } \\
\text { efficiency } \\
\text { score }\end{array}$ & $\begin{array}{c}\text { Technical } \\
\text { efficiency } \\
\text { rank }\end{array}$ & Reference set \\
\hline Kuwait & 4 & 3 & 2.319 & 1 & \\
\hline Georgia & 22 & 18 & 1.140 & 2 & \\
\hline Venezuela & 31 & 16 & 1.139 & 3 & \\
\hline Russia & 16 & 4 & 1.045 & 4 & \\
\hline Jamaica & 30 & 25 & 1.041 & 5 & \\
\hline Poland & 29 & 11 & 1.015 & 6 & \\
\hline Albania & 27 & 15 & 1.007 & 7 & \\
\hline Ukraine & 19 & 21 & 1.007 & 8 & \\
\hline Romani & 21 & 5 & 1.007 & 9 & \\
\hline Armenia & 23 & 27 & 0.972 & 10 & $\begin{array}{c}\text { Albania, Georgia, } \\
\text { Jamaica }\end{array}$ \\
\hline Montenegro & 18 & 2 & 0.965 & 11 & $\begin{array}{c}\text { Poland, Kuwait, Albania, } \\
\text { Georgia }\end{array}$ \\
\hline Lebanon & 28 & 17 & 0.959 & 12 & $\begin{array}{l}\text { Romania, Kuwait, } \\
\text { Venezuela }\end{array}$ \\
\hline Trinidad & 24 & 13 & 0.955 & 13 & $\begin{array}{c}\text { Kuwait, Venezuela, } \\
\text { Georgia }\end{array}$ \\
\hline Ecuador & 25 & 28 & 0.955 & 14 & Georgia \\
\hline $\begin{array}{c}\text { Bosnia and } \\
\text { Herzegovina }\end{array}$ & 26 & 22 & 0.951 & 15 & Albania, Venezuela \\
\hline Bulgaria & 14 & 6 & 0.944 & 16 & $\begin{array}{c}\text { Poland, Kuwait, Russia, } \\
\text { Georgia }\end{array}$ \\
\hline Azerbaijan & 7 & 23 & 0.933 & 17 & $\begin{array}{l}\text { Poland, Kuwait, Russia, } \\
\text { Georgia }\end{array}$ \\
\hline Uruguay & 20 & 1 & 0.919 & 18 & $\begin{array}{c}\text { Kuwait, Venezuela, } \\
\text { Georgia }\end{array}$ \\
\hline Iran & 15 & 19 & 0.899 & 19 & Albania, Venezuela \\
\hline Costa Rica & 11 & 10 & 0.888 & 20 & Albania, Venezuela \\
\hline Tunisia & 12 & 31 & 0.879 & 21 & Venezuela \\
\hline Kazakhstan & 9 & 14 & 0.873 & 22 & $\begin{array}{c}\text { Serbia, Kuwait Russia } \\
\text { Georgia }\end{array}$ \\
\hline Panama & 5 & 8 & 0.868 & 23 & $\begin{array}{c}\text { Serbia, Kuwait, Albania, } \\
\text { Venezuela }\end{array}$ \\
\hline Peru & 13 & 20 & 0.854 & 24 & Venezuela, Georgia \\
\hline Mexico & 10 & 9 & 0.851 & 25 & $\begin{array}{c}\text { Kuwait, Venezuela, } \\
\text { Georgia }\end{array}$ \\
\hline Colombia & 17 & 30 & 0.830 & 26 & Georgia \\
\hline Oman & 3 & 24 & 0.808 & 27 & Kuwait, Venezuela \\
\hline Turkey & 6 & 29 & 0.785 & 28 & Kuwait, Venezuela \\
\hline Brazil & 8 & 26 & 0.780 & 29 & Georgia \\
\hline Malaysia & 2 & 12 & 0.775 & 30 & $\begin{array}{c}\text { Serbia, } \\
\text { Kuwait, Venezuela, } \\
\text { Albania }\end{array}$ \\
\hline Saudi Arabia & 1 & 7 & 0.754 & 31 & $\begin{array}{c}\text { Kuwait, Venezuela, } \\
\text { Georgia }\end{array}$ \\
\hline
\end{tabular}

Source: results of the study 


\subsection{Value Target of Subindexes of Human Development}

Column 2, 4, and 6 of table 3 show value target of each subindex of human development that causes the underlying country to achieve efficiency frontier. Consequently, column 3, 5, and 7 of the table show the change needed to achieve the goal i.e. being efficient. According to the table, for efficient countries, value target and actual value (table 1) are equal. Subsequently, the change needed to achieve efficiency frontier is equal to zero.

Table 3. Target and increasable values in order to attain efficiency frontier in 2012.

\begin{tabular}{|c|c|c|c|c|c|c|}
\hline \multirow{2}{*}{ Country/Economy } & \multicolumn{2}{|c|}{$\begin{array}{c}\text { life expectancy at birth } \\
\text { (year) }\end{array}$} & \multicolumn{2}{|c|}{$\begin{array}{c}\text { mean years of schooling } \\
\text { (year) }\end{array}$} & \multicolumn{2}{|c|}{$\begin{array}{l}\text { per capita national } \\
\text { income (dollar) }\end{array}$} \\
\hline & $\begin{array}{l}\text { Target } \\
\text { value }\end{array}$ & $\begin{array}{c}\text { Increasable } \\
\text { value }\end{array}$ & $\begin{array}{l}\text { Target } \\
\text { value }\end{array}$ & $\begin{array}{c}\text { Increasable } \\
\text { value }\end{array}$ & $\begin{array}{l}\text { Target } \\
\text { value }\end{array}$ & $\begin{array}{c}\text { Increasable } \\
\text { value }\end{array}$ \\
\hline Uruguay & 83.99 & 6.79 & 9.25 & 0.75 & 14505 & 1172 \\
\hline Romania & 74.20 & 0 & 10.40 & 0 & 11011 & 0 \\
\hline Montenegro & 77.53 & 2.73 & 10.88 & 0.38 & 10854 & 383 \\
\hline Bulgaria & 78.00 & 4.40 & 11.23 & 0.63 & 12160 & 686 \\
\hline Saudi Arabia & 98.21 & 24.11 & 10.34 & 2.54 & 29975 & 7359 \\
\hline Mexico & 90.62 & 13.52 & 9.99 & 1.49 & 15216 & 2269 \\
\hline Panama & 87.94 & 11.64 & 10.83 & 1.43 & 15581 & 2062 \\
\hline Poland & 74.70 & 0 & 10.20 & 0 & 9533 & 0 \\
\hline Malaysia & 96.16 & 21.66 & 12.26 & 2.76 & 17652 & 3976 \\
\hline Trinidad & 73.62 & 3.32 & 9.63 & 0.43 & 22976 & 1035 \\
\hline Kuwait & 74.70 & 0 & 6.10 & 0 & 52793 & 0 \\
\hline Russia & 69.10 & 0 & 11.70 & 0 & 14461 & 0 \\
\hline Kazakhstan & 77.19 & 9.79 & 11.91 & 1.51 & 11970 & 1519 \\
\hline Albania & 77.10 & 0 & 10.40 & 0 & 7822 & 0 \\
\hline Cota Rica & 89.46 & 10.06 & 9.46 & 1.06 & 13205 & 2342 \\
\hline Lebanon & 75.91 & 3.11 & 8.24 & 0.34 & 12892 & 528 \\
\hline Venezuela & 74.60 & 0 & 7.60 & 0 & 11475 & 0 \\
\hline $\begin{array}{l}\text { Bosnia and } \\
\text { Herzegovina }\end{array}$ & 79.70 & 3.90 & 8.73 & 0.43 & 11296 & 3583 \\
\hline Georgia & 73.90 & 0 & 12.10 & 0 & 5005 & 0 \\
\hline Ukraine & 68.80 & 0 & 11.30 & 0 & 6428 & 0 \\
\hline Jamaica & 73.30 & 0 & 9.60 & 0 & 6701 & 0 \\
\hline Peru & 86.89 & 12.69 & 10.19 & 1.49 & 11507 & 2201 \\
\hline Brazil & 94.62 & 20.82 & 9.64 & 2.44 & 14554 & 4402 \\
\hline Ecuador & 79.34 & 3.54 & 8.08 & 0.48 & 12205 & 4734 \\
\hline Armenia & 76.51 & 2.11 & 11.11 & 0.31 & 6793 & 1253 \\
\hline Colombia & 89.05 & 15.15 & 9.07 & 1.77 & 13697 & 4986 \\
\hline Iran & 81.42 & 8.22 & 8.68 & 0.88 & 11920 & 1225 \\
\hline Oman & 90.59 & 17.39 & 8.65 & 3.15 & 29817 & 5725 \\
\hline Azerbaijan & 75.97 & 5.07 & 12.00 & 0.80 & 8736 & 583 \\
\hline Turkey & 94.51 & 20.31 & 9.52 & 3.02 & 17463 & 3753 \\
\hline Tunisia & 84.95 & 10.25 & 8.65 & 2.15 & 13067 & 4964 \\
\hline
\end{tabular}

Source: results of the research 
According to the table, in this year, Saudi Arabia, Malaysia, Brazil, and Turkey have the most difference between actual and target values in the life expectancy subindex, Oman and Turkey in mean years of schooling, and Saudi Arabia and Oman in per capita GNI.

\subsection{Sensitivity Analysis}

By the sensitivity analysis we aim to assess sensitiveness of countries' efficiency score to each input and output variables in DEA method. So, we exclude one of the input or output variables from the model and recalculate efficiency score of the underlying unit and compute the resulting difference.

Table 4. Sensitivity analysis.

\begin{tabular}{|c|c|c|c|c|c|c|c|}
\hline \multirow[b]{2}{*}{ Country/Economy } & \multirow[b]{2}{*}{$\begin{array}{l}\text { Primary } \\
\text { efficiency } \\
\text { score }\end{array}$} & \multicolumn{6}{|c|}{ Efficiency score resulted by excluding: } \\
\hline & & $\begin{array}{c}\text { Life } \\
\text { expectancy }\end{array}$ & $\begin{array}{c}\text { Mean } \\
\text { years of } \\
\text { schooling }\end{array}$ & $\begin{array}{l}\text { Per } \\
\text { capita } \\
\text { GNI }\end{array}$ & $\begin{array}{c}\text { Basic } \\
\text { requirements }\end{array}$ & $\begin{array}{l}\text { Efficiency } \\
\text { enhancers }\end{array}$ & $\begin{array}{c}\text { Innovation } \\
\text { and } \\
\text { sophistication } \\
\text { factors }\end{array}$ \\
\hline Uruguay & 0.92 & 0.76 & 0.91 & 0.91 & 0.85 & 0.85 & 0.92 \\
\hline Romania & 0.99 & 0.94 & 0.88 & 0.94 & 0.99 & 0.99 & 0.98 \\
\hline Montenegro & 0.92 & 0.88 & 0.86 & 0.90 & 0.90 & 0.90 & 0.92 \\
\hline Bulgaria & 0.96 & 0.92 & 0.86 & 0.91 & 0.96 & 0.96 & 0.96 \\
\hline Saudi Arabia & 0.76 & 0.69 & 0.75 & 0.72 & 0.74 & 0.74 & 0.76 \\
\hline Mexico & 0.87 & 0.77 & 0.86 & 0.87 & 0.86 & 0.86 & 0.87 \\
\hline Panama & 0.90 & 0.81 & 0.87 & 0.89 & 0.86 & 0.86 & 0.90 \\
\hline Poland & 1.00 & 0.92 & 0.94 & 0.99 & 1.00 & 1.00 & 0.99 \\
\hline Malaysia & 0.76 & 0.71 & 0.72 & 0.74 & 0.75 & 0.75 & 0.76 \\
\hline Trinidad & 0.95 & 0.95 & 0.88 & 0.88 & 0.95 & 0.95 & 0.95 \\
\hline Kuwait & 2.24 & 2.24 & 2.24 & 0.86 & 2.19 & 2.19 & 2.24 \\
\hline Russia & 1.03 & 1.03 & 0.82 & 0.91 & 1.03 & 1.03 & 1.03 \\
\hline Kazakhstan & 0.93 & 0.92 & 0.84 & 0.89 & 0.93 & 0.93 & 0.88 \\
\hline Albania & 0.97 & 0.87 & 0.93 & 0.97 & 0.95 & 0.95 & 0.97 \\
\hline Cota Rica & 0.91 & 0.74 & 0.91 & 0.91 & 0.86 & 0.86 & 0.91 \\
\hline Lebanon & 0.93 & 0.83 & 0.91 & 0.90 & 0.93 & 0.93 & 0.93 \\
\hline Venezuela & 1.14 & 0.86 & 1.14 & 1.13 & 1.14 & 1.14 & 1.11 \\
\hline $\begin{array}{l}\text { Bosnia and } \\
\text { Herzegovina }\end{array}$ & 0.99 & 0.76 & 0.97 & 0.99 & 0.93 & 0.93 & 0.99 \\
\hline Georgia & 1.13 & 1.13 & 0.93 & 1.13 & 1.12 & 1.12 & 1.12 \\
\hline Ukraine & 0.99 & 0.99 & 0.80 & 0.97 & 0.99 & 0.99 & 0.99 \\
\hline Jamaica & 1.04 & 0.95 & 0.95 & 1.04 & 1.04 & 1.04 & 1.04 \\
\hline Peru & 0.86 & 0.77 & 0.85 & 0.86 & 0.86 & 0.86 & 0.85 \\
\hline Brazil & 0.83 & 0.68 & 0.83 & 0.83 & 0.83 & 0.83 & 0.83 \\
\hline Ecuador & 1.00 & 0.72 & 1.00 & 1.00 & 0.90 & 0.90 & 1.00 \\
\hline Armenia & 0.99 & 0.92 & 0.93 & 0.99 & 0.97 & 0.97 & 0.99 \\
\hline Colombia & 0.84 & 0.64 & 0.84 & 0.84 & 0.80 & 0.80 & 0.84 \\
\hline Iran & 0.92 & 0.74 & 0.91 & 0.91 & 0.83 & 0.83 & 0.92 \\
\hline Oman & 0.83 & 0.61 & 0.83 & 0.79 & 0.77 & 0.77 & 0.83 \\
\hline Azerbaijan & 0.91 & 0.91 & 0.83 & 0.89 & 0.90 & 0.90 & 0.91 \\
\hline Turkey & 0.83 & 0.64 & 0.83 & 0.82 & 0.80 & 0.80 & 0.83 \\
\hline Tunisia & 0.85 & 0.55 & 0.85 & 0.85 & 0.73 & 0.73 & 0.85 \\
\hline \multicolumn{2}{|c|}{$\begin{array}{l}\text { Average difference between } \\
\text { new and primary efficiency } \\
\text { scores }\end{array}$} & 0.09 & 0.06 & 0.06 & 0.02 & 0.03 & 0.00 \\
\hline
\end{tabular}


In the table 4, the last column shows average deviation of efficiency score of the countries in response to exclusion of every subindex and consequently, every country for that the resulting differentiation is upper than the average, regarded as sensitive to the considered subindex.

Sensitivity analysis shows that Tunisia, Ecuador, Venezuela, Oman, Bosnia and Herzegovina, Iran, Turkey, Columbia, Uruguay, and Costa Rica have the most sensitivity to life-expectancy-at-birth subindex, respectively. In other word, these countries have used lifeexpectancy-at-birth subindex efficiently.

Ukraine, Georgia, Russia, Romania, Jamaica, Azerbaijan, Bulgaria, Kazakhstan, Montenegro, Armenia, and Serbia have the most change in efficiency score by excluding mean-years-of-schooling subindex, respectively.

Kuwait, Russia, and Trinidad are sensitive to per-capita-income subindex. In other word, these countries have made optimal use of income to improve their performance.

Jamaica, Ukraine, Lebanon, Romania, Venezuela, and Bulgaria, respectively, have the most sensitivity to basic-requirements subindex.

Tunisia, Iran, Bosnia, Uruguay, Oman, Costa Rica, Trinidad, and Georgia are sensitive to efficiency-enhancers subindex, respectively.

Russia, Peru, Georgia, Venezuela, and Serbia, respectively, have the most sensitivity to innovation subindex suggesting that these countries have efficiently used innovation to improve their performance.

\subsection{Detailed Analysis for Iran}

According to table 2, in 2012 Iran is an inefficient unit, having a technical efficiency rank of 19th among the assessed countries. Moreover, Albania and Venezuela have been introduced as patterns for Iran in this year. As in this paper there are two kinds of variables, i.e. input and output variables, table 4 shows that the most effective subindex which have sharply lowered Iran's score are life expectancy at birth for input variables and efficiency enhancers for output variables. This implies that Iran used these subindexes efficiently, because excluding them hurts efficiency score intensively. Moreover, table 3 shows that Iran should rise its life expectancy subindex by 8.22 years or increase mean years of schooling by 0.88 year or augment its per capita national income by US\$ 1225 in order to attain relative efficiency in 2012.

\section{CONCLUSIONS}

Competitiveness and human development are two major aspects of nations' performance. However, the main goal of competitiveness should be to improve human development. In the current study, we aimed to assess whether countries achieve the target. In other word, whether competitiveness have led to human development. Thereupon, we selected 31 countries with same category of human development (high human development) as well as available data on competitiveness and its components. Because of nature of the study we used Data Envelopment Analysis (DEA) method. The model used in this study employed three subindexes of global competitiveness including basic requirements, efficiency enhancers, and innovation and sophistication factors (Report, Schwab, and Forum 2013) as input variables and three subindexes of human development including life expectancy at birth, mean years of 
schooling, and per capita national income (UNDP, 2013) as output variables. Since, as said, the goal of countries (DMUs) is to improve human development, this study applies an outputoriented DEA model. Though, a DEA model can be used with either constant or variable return to scale, this paper employs DEA with constant return to scale because variable case has extended to accommodate scale effects while in our case (where countries in the role of units under assessment are large enough) inherent scale effects don't exist and also CRS models have higher separability power for efficient and inefficient units (Dyson et al. 2001). And finally after running the model we attained the following results:

9 countries of 31 assessed countries are technically efficient implying that these 9 countries have used competitiveness subindexes to attain expected values of human development subindexes (table 1).

Saudi Arabia, Malaysia, Tunisia and Oman, which usually have top rankings in competitiveness, couldn't use this potential ability to increase their welfare and consequently, have ranked down in technical efficiency.

Uruguay and Montenegro, which have ranked top in human development, are technically inefficient implying that these countries should do better in human development index to achieve efficiency frontier.

\section{References}

[1] Andersen, Per, and Niels Christian Petersen. 1993. "A Procedure for Ranking Efficient Units in Data Envelopment Analysis.” Management Science 39(10): 1261-64. http://dx.doi.org/10.1287/mnsc.39.10.1261.

[2] Banker, R D, A Charnes, and W W Cooper. 1984. "Some Models for Estimating Technical and Scale Inefficiencies in Data Envelopment Analysis." Management Science 30(9): 1078-92. http://dx.doi.org/10.1287/mnsc.30.9.1078.

[3] Boltho, A. 1996. "The Assessment: International Competitiveness." Oxford Review of Economic Policy 12 (3 ): 1-16. http://oxrep.oxfordjournals.org/content/12/3/1.short.

[4] Charnes, A, W.w Cooper, and E Rhodes. 1978. "Measuring the Efficiency of Decision Making Units." 2: 429-44.

[5] Davies, Antony. 2009. "Human Development and the Optimal Size of Government." Journal of Socio-Economics 38(2): 326-30.

http://linkinghub.elsevier.com/retrieve/pii/S1053535708001236 (August 1, 2014).

[6] Dyson, R.G. et al. 2001. "Pitfalls and Protocols in DEA.” European Journal of Operational Research 132(2): 245-59.

http://linkinghub.elsevier.com/retrieve/pii/S0377221700001491.

[7] Önsel, Şule et al. 2008. "A New Perspective on the Competitiveness of Nations." SocioEconomic Planning Sciences 42(4): 221-46.

http://www.sciencedirect.com/science/article/pii/S0038012108000025 (August 11, 2014).

[8] Ranis, Gustav, and Alejandro Ramirez. 2000. "Economic Growth and Human Development." 28(2). 
[9] Reiter, S.L., and H. Kevin Steensma. 2010. "Human Development and Foreign Direct Investment in Developing Countries: The Influence of FDI Policy and Corruption." World Development 38(12): 1678-91.

http://linkinghub.elsevier.com/retrieve/pii/S0305750X10000926 (October 16, 2014).

[10] Report, Insight, Klaus Schwab, and World Economic Forum. 2013. The Global Competitiveness Report.

[11] UNDP, Human Development Report, 2013.

[12] Sadeghi, Hossein, Soulmaz Abollahi Haghi, and Leila Abdollah Zadeh. 2007. "Human Development in Iran (Persian Text)." Social Walfare (24): 281-304. http://www.noormags.ir/view/fa/articlepage/947694.

[13] Ülengin, Füsun et al. 2011. "The Competitiveness of Nations and Implications for Human Development." Socio-Economic Planning Sciences 45(1): 16-27. http://www.sciencedirect.com/science/article/pii/S0038012110000467 (October 16, 2014).

[14] Ulengin, Fusun, Burç Ulengin, and Sule Onsel. 2002. "A Power-Based Measurement Approach to Specify Macroeconomic Competitiveness of Countries." Socio-Economic Planning Sciences 36(3): 203-26.

http://www.sciencedirect.com/science/article/pii/S0038012101000210 (November 26, 2014).

[15] Wang, Tai-Yue, Shih-Chien Chien, and Chiang Kao. 2007. "The Role of Technology Development in National Competitiveness - Evidence from Southeast Asian Countries." Technological Forecasting and Social Change 74(8): 1357-73. http://www.sciencedirect.com/science/article/pii/S0040162507000029 (October 9, 2014).

[16] WEF, Global Competitiveness Report, 2013. 